\title{
DECENTRALIZATION FOR NATIONAL DEVELOPMENT IN NIGERIA FROM A CONTEXTUAL VIEW OF ANCIENT ISRAELITE SYSTEM OF EGALITARIAN STEWARDSHIP AND ACCOUNTABILITY
}

\author{
Abiola A. Olaniyi* \\ http://dx.doi.org/10.4314/og.v10i 1.9
}

\begin{abstract}
National development of a multicultural setting requires a decentralized appropriation of diverse contributions of various constituent subsets. Improvement of multicultural settings calls for social negotiation and economic merger, and compression of individual resources of the various units to enhance egalitarian level of advancement. However, the Nigerian government employed a centralized authoritarian administration that undermined the value of economic relations and national development since military rule in 1966. Centralization of the control of economic and entrepreneurial ventures culminated in economic deprivations among the states and regions of Nigeria. Consequently, increase in level of poverty became pronounced while resources of development existed untapped in the local areas. This paper employed historical critical analysis in contextualizing solutions to the above problems while suggesting the need to encourage individual creativity in entrepreneurship in order to enlarge multi economic relations for national development. It concluded by recommending Israelite egalitarian system of stewardship and accountability for a decentralization of economic control towards improvement of the rural constituent regions. There should also be fund from the Federal Government to establish industries in the rural areas. There is need for exploration of resources at the local areas by local trade societies saddled with stewardship of $20 \%$ of gross local products to the Federal treasury in order to expand employment opportunities.
\end{abstract}




\section{Introduction}

Nigeria is characterized by a mixed origin of different tribal/regional constituencies that form its multicultural settings. Every tribal/regional constituency had land, water and air spaces that were listed as natural tourist centres and wells of mineral resources. But these natural resources of industrial entrepreneurship and employment were repossessed by the autocratic military rulers and business moguls. These autocratic industrialists served the whims and caprice of the junta as policy makers of the authoritarian system. This centralization of control of economic and entrepreneurial ventures accentuated economic deprivations in Nigeria. Initial owners of the land and water spaces as local families, households, clans, and tribes were made to serve under a highly centralized tax and price control system. Land use decrees were promulgated to seize the natural resources below, on and above the farmlands by the military junta till the initial land owners enrolled as disposable labour on the same lands which they used to own by household/tribal inheritance. Unfortunately, lands and water spaces in the rural areas where more youths and human resources for labour resided were left uncultivated while urban industrial network attracted the youths to migrate from the rural setting of land ownership. The attending challenges are overpopulation, destitution, and increase in crime rate in the cities. The economic deprivation also produced entrepreneurial poverty and undermined opportunities of employment in the diverse ethnic and religious identities that amalgamated to form the nation. These challenges (economic deprivation, entrepreneurial poverty, and weaker bases for employment of labour) began with the British colonial rule in Africa. Military rule in Nigeria multiplied the condition of deprivations by ruling with decrees as authoritarians in pursuit of autocracy.

The thesis statement of this paper therefore, proposes rural development scheme of locating industries next to raw materials in the rural areas. Location and localization of industries in proximity 
of material and human resources that are always resident in the rural areas will make factories of employment available at the door-step of rural dwellers for national development. A system of egalitarian stewardship and accountability which assisted the age of tribal prosperity in Israel is recommended as a solution to the problematic situation in Nigeria.

\section{The Contexts of the Problem}

Two contexts led to the emergence of economic deprivations in Nigeria. First, Nigeria had a mixed origin from merger of different tribal regions which became its constituent subsets during the British colonial rule. The tribes/regions were made to supply human and material resources for the British colonial system at the centre against industrialization of the local regions. Whereas the tribal regions initially existed as a confederacy of tribes under tribal leaders who served the interest of their tribal holdings and whose authorities were under checks of council of household leaders, kingmakers, and rallied masses. The allegiance of the leaders of the regions was towards the improvement of their local settings. Second, Nigeria witnessed military aberration in politics as its period of centralization of authority under absolute authoritarians. Attention was directed at making few juntas (elites in the military and coup sponsoring merchants) the controllers of economic transactions for the nation. Centralization of economic control created the deprivations that undermined national development of the rural areas.

\section{The Creation of the Problem}

British colonial system enforced varied forms of coercive or authoritarian system that centralized political control of socioeconomic resources of the diverse tribes/regions that were merged to form Nigeria in the $20^{\text {th }}$ century. Traditional customs and leaders (kings as Obas, Emirs, and Igwes) were redirected to reject values of preserving their local communities in order to make them comply with the British system. This approach downgraded social and 
economic relationships in the regions and devalued the continuity and welfare of their constituent subsets. Concern for actualization of totalitarian agenda of the centralized political and economic control held sway to create a dearth of rightful means of exploring agricultural, commercial and mineral resources on the land, in the air and under the ground/water spaces of the regions.

Advent of Military aberration in democratic politics in Nigeria worsened the problematic state of the nation with varied practices of absolute authority and centralized system. There was a misplacement of priority away from (a) defense and security of the nation against civil disorder and external aggression; (b) construction and channelization of road networks among the regions for inter-state connections, and (c) provision of electricity and communication technologies that private and non-governmental organizations could access in creating employment of labour, manufacture of primary products, and production of food and cash crops in the local regions. Rather, military decrees in Nigeria undermined entrepreneurial creativity and ingenuity of the Nigerian citizenry. The State encroached upon the rights of her citizens; by creating some government controlled corporations saddled with registration, establishment, and structuring of network of business relations (of private firms/industries) and fixing of prices of cash and manufactured products. The public corporations monopolized employment opportunities in the agricultural, industrial, and commercial investments as well as electricity and telecommunications. The military dictatorship confined ownership and control of media houses and basic educational institutions to the autocratic junta and deprived many Nigerians of atmosphere for creation of bases of employment and free atmosphere for upward mobility of labour in gainful employment opportunities. The deprivations are major impediments of economic transformation and national development in Nigeria today.

So, Nigeria is presented as a paradox of one of the six richest petroleum exporting countries (OPEC) in the world and one 
of twenty five poorest countries of the world by United Nations Development Programme (UNDP). ${ }^{\text {i }}$ It is also embarrassing to note that "in the year 2000, Africa remained the least developed region of the world, following forty years of varying development policies that broadly commenced with the beginning of the independence era in 1960." This is because Africans have continued to serve the British colonial form of industrialization which provided four colonial options consisting of (i) "development of the mining industries," (ii) "emphasis upon the production and export of agricultural and mineral raw materials," (iii) "establishment of oil-related industries to service the petroleum sector," and (iv) "development of tourism." These four colonial forms of industrialization deprived local control of raw materials and rural development because they were directed at meeting the needs of foreign companies of the colonialists. They have continued to haunt industrial creativity and economic ingenuity in spite of several attempts by Nigerian government to follow the general pattern and same lines of industrialization "created by the colonial powers."ii

\section{Economic Deprivation under Colonial Rule in Nigeria}

Prior to the incarceration from British system, slave labour in the traditional system served in growing both northern emirate economies (cotton and groundnut in the caliphate's plantation) and southern royal market (palm-oil business in Yoruba land and NigerDelta). The traditional leaders and the elites controlled the economy and determined the pace of development. ${ }^{\text {ii }}$ Within this background, Britain "engaged in the political economy of the West African coast" owing to "the need for raw materials such as cotton and palm oil to feed its industries and for markets to sell its manufactures." Extension of British concern "opened up the Yoruba country to civilizing missionary influence...the British bombarded and conquered Lagos in 1851." However, "tension over the control of the trade routes to the interior repeatedly brought the British into conflict with Ijebu, Egba, and Ibadan... New Oyo and Ilorin had to be compelled by force of arms to submit to the colonial forces." 
Economic deprivation multiplied between 1882 and 1897, as "British forces of the UAC and the Lagos government marched against African forces in Yoruba land and the Niger Delta." Hostilities against northern states of the Sokoto Caliphate were led by Frederick Lugard between 1900 and 1903 under "the European technical superiority in warfare." Tiv people were later subjugated to unite the Protectorates of Southern Nigeria and Northern Nigeria at "the amalgamation in 1914.",

History also records that the development that occurred in the formation of Nigeria from its rural life to urban transformation began with British colonial abuse of African labour skill. It asserts that European interest in nineteenth-century Africa was heavily prejudiced by concerns for economic and humanitarian controls. In addition, "the last vestiges of a complex system of labour exploitation that developed significantly in the nineteenth century were undermined by European colonial control in the twentieth century." Little wonder, the mentality of exploiting skilled labour by paying peanuts continued to multiply in Nigeria "as a concomitant of the state-building revolution which swept across Africa."vi With a superior military power, the British Colonial System of Pre-Independence era (BCS) amalgamated different ethnic regions and dialects to create the largest British Colony called Nigeria in 1914. The BCS introduced a poor workers' distribution system which later became popular and known as Public Works Department (PWD). The PWD was designed to address inability of the British forces to rally a sufficient number of manpower needed against African forces in Yoruba land and the Niger Delta and especially in wooing more Africans to serve in the British owned firms in Nigeria. ${ }^{\text {vii }}$ The civilian rules of Post Independence era engaged the armed forces to protect bureaucracies of state owned corporations against free trade forum of private entrepreneurship till military rule began in 1966 in Nigeria. 


\section{Centralized Authority of the Military Rule in Nigeria}

Post-Independence era in Nigeria witnessed incessant military aberration in democratic politics. The military exploited "the new found access to the privileges associated with leadership, such as luxury housing and access to state wealth" just like the civilian regimes that they ousted from governance had done. Before long, "military-dominated patterns of corruption steadily emerged" in and throughout the military regimes that governed the nation. Military rule hijacked ownership and control of privately established schools (from primary schools to tertiary institutions) and media houses (to monopolize the control of information and communication) that provided employment for most Nigerian populace. The authoritarian approach of the Military did not create "political compacts through the use of political bargaining" with previously existing zonal and private economic establishments of the Pre-Colonial era. The Military suppressed diversity of private entrepreneurial ventures that would have facilitated multi economic system of diverse zonal/regional explorations at the Local and State Governments of the federation. The masses protested against military adoption of centralized control of the economic sphere which among other things (a) "intensified public alienation," (b) deepened "the sense of acute injustice" in the nation, and (c) hindered expansion of "gross national products (GNPs), greater levels of domestic investment, and higher levels of export."viii

These economic deprivations from Federal Public Service and State Civil Service fomented a kind of abuse of labour/workers. It introduced both a part-time or casual labour system (temporary appointment that was disposable anytime without retirement benefit) and over-time jobs (conscription to work beyond daily and conventional 8 hours of service). Part-time and over-time jobs were not equally remunerated for providing same skill labour as done for permanent employment of 8.a.m to 4.p.m labour system. Nigeria grappled with blind-race for white-collar and blue-collar jobs with/without certificates to prove their skills. Fear of job insecurity, exposure to economic deprivation of working as casual labour 
without retirement benefit and threat of non-employable age (for people above 40 years) into corporate businesses fomented a vice of obtaining sworn affidavits to replace birth certificates in the age forgery and reduction bids.

Nigeria should then be rated as a poor nation of economically deprived people. This was because; Nigerian masses earned wages below Nigerian national income per capital. More so, 2005 World Summit described poverty as a state of earning low income per capital. It stated that whenever the income of a community was less than forty percent of her capital subdivisions (individuals, families, relatives or lineage) there was poverty in the entity. ${ }^{\text {ix }}$ Deprivation form of poverty was then assumed to be inability to provide; owing to a deprivation of access to basic needs of life. This form of poverty was measured by placing what the poor labour earned for doing the same skilled labour that the rich occupants of executive positions of appointments earned in comparison with or relation to standard of living of the affluent or wealthy people in the same society. In that light, "people are poor, not only in relation to their needs, but also in relation to other people who are not poor." ${ }^{\mathrm{x}}$ So, "Nigeria presents a paradox. The country is rich, but the people are poor." ${ }^{\text {, }}$ The problematic condition of the nation has become unavoidably confrontational for people asking "what can be done to relieve the citizens of the burden?"

\section{Attempts towards Economic Transformation}

Post-independence civil war, military coups and rules, regional complaint of marginalization and inter-tribal/ethnic conflicts prevented Nigeria from practicing regional/state control of material resources that laid under individual state's geographical boundary. The ripple effects of the Nigerian civil war and other inter-ethnic clashes created a fear of possibility of withdrawal of some states that constituted an ethnic identity from the amalgamation called Nigeria. The centralized system of administration disguised as a federal system was enforced to continue in order to avoid secession. The 
Federal Government of Nigeria (FGN) doled out peanuts to State Governments (SGs) for the purposes of subordinating the ingenuity of SGs to FGN. This attempt made the Local Governments (LGs) under SGs to be at the mercy of the SGs. The LGs were denied of their full remunerations as the real land owners, and producers and possessors of resources in their air-space, on their land-space and under their ground or in their water-space. As the FGN denied the SGs their benefits, so also the LGs were denied their benefits by the SGs.

A new system of social stratification that supported the prosperity of the ruling caucus against the welfare of the lower class/peasants who worked as casual labour/part-time stewards also developed. There was a repetition of the British system of creation of lower class, middle class elites (working for the British corporations) and the upper class of government policy makers. The wealth of the elites was supported by various Poverty Alleviation Programmes (PAPs) of the FGN. Landed properties in Government Reservation Areas (GRAs) and financial allowances and mouthwatery furnished appointments were offered to the middle class in order to win their loyalty and up-lift their prestige against the lower class in the nation.

Consequently, the elites purchased privatized public corporations in order to control access to available basic amenities and needs of life. Loans were issued at very high interest rates to peasants who demonstrated entrepreneurial ingenuity till they became indebted to the ruling caucus and the middle class that lived in the GRAs. High tenement tax rates and high cost of registering small scale firms forced the entrepreneurial lower class to sell their firms and the lands. So, the real producers of labour and raw materials (as peasants and the economically deprived) became stewards of the elite class and the ruling caucus that controlled the use of the products and the exploitation of the surplus of production. Till date, there is exportation of raw materials and food crops grown in Nigeria for the land of the ex-colonial masters. 
There are other programmes from Non-Governmental Organizations (NGOs), individuals and corporate bodies including the religious institutions establishing different purpose-oriented foundations, alms giving schemes, sponsorship/scholarship, and love feast services. Yet, the communiqués of conferences of religious and Non-Governmental Organizations and other press releases have proved ineffective. The Education Quota System (EQS) of providing financial sponsorship and instructional infrastructure to some parts of the country at the neglect of other regions has multiplied the discomfort of the masses. Instead of building even-educational development in the regions that make Nigeria, the EQS has produced a deprivation of student's brilliance and talent for admission, an inequality in educational system, and a lack of unity. Poor people's home scheme called Rehabilitation Homes no longer has adequate maintenance, making them to appear like prison yards. Alms giving, financial sponsorship and love feasts are abused, as begging becomes a new form of business for earning a living! "Most development projects in Nigeria have only succeeded in making the top privileged few richer, with the majority not benefiting at all."

Ositelu sums it up by saying that the strategies of eradicating or alleviating poverty with all their good intentions have all failed. Failure occurred because the programmes were politicized to attend to those who were relatives of members of the directorates or commissions and close to the ruling political party. The programmes became ineffective when the number of directorates and schemes commissioned for the same purpose became so many to the extent that poverty ameliorating programmes became job creation approaches and government offices for financial allocations without portfolio. Consequently, factors of economic deprivation for poverty to multiply are abetted so as to sustain the continuous existence of the ameliorating programmes, as means of earning a living for members of the commissions. The PAPs have not been unable to make any tangible difference in reducing the number of the poor and unemployed graduates in the country. Some poverty ameliorating 
foundations and schemes of NGOs have also become mere outlets of swindling the unsuspecting poor and members of the society. ${ }^{\text {xii }}$ Suffice to say that "... although uncountable number of solutions have been proffered towards 'eliminating' or 'alleviating' poverty, none has really achieved the purpose for which it was designed." Therefore, economic poverty as a product of lopsided access to the ability to change one's state and status owing to deprivation is a characteristic of centralization of control of city economic life. It has culminated in a reversal of the age of prosperity in Africa during the Pre-Colonial Era (from rural economic adroitness for urban and centralized gaucheness on economic relations). Entrepreneurial ingenuity flourished under private enterprises and communal economic ventures during rural and decentralized economic nimbleness. But, centralization of cash crop farming, commerce, industry and exploration of mineral resources in making primary products created a ravished trade zone of competition for the asymmetrical access to and disproportionate number of national resources. There should not be continuation and multiplication of ineffective strategies. Attention should be directed at decentralizing the control of economic production towards amelioration of the condition of Nigerian masses leaving the rural areas to overpopulate the cities.

\section{Israelite Egalitarian System of Stewardship and Accountability of Constituent Tribes}

There is an adage that the treaty of sovereign identity among varied ethnocentric peoples usually becomes the context of their amalgamation, stewardship and continual togetherness. This adage found exposition in the system of equal recognition of constituent tribes practiced in ancient Israel. It also led to the establishment of even system of tribal stewardship and accountability in Israel. It is expected to provide a springboard for decentralization of economic control towards the development of rural areas in Nigeria.

Owing to the topography of Canaan where the twelve tribal holdings resided, the confederacy adopted a system of exploration of 
the resources of individual tribal lands subject to checks and balances from the union of households and clans that made up each tribe. This pre-monarchic Israel was a peasant movement with egalitarian relations against the hierarchical system of city-state life of the Near East. The relatively egalitarian system was built around the Mosaic covenant and charismatic servant-leadership style. Equal distribution and recognition of households and services were also developed in response to Israelite challenges as a frontier. ${ }^{\mathrm{x}}$ The inheritance of every tribe especially its tribal lands were not transferable from one tribe to another tribe. Rather, each tribe managed proceeds of both private and household professions under separate clans that were compacted to assist and control trading of food and cash crops and products of animal husbandry in her land (Num. 1:18\&19; 1:44 \& 45; 2:1 \& 2; 24:2; 26:52-56; 33:53 \& 54; 36:6-9,12; Deut. 19:14). Every tribe under the system of "tribal holding was in possession of those holdings that would be theirs through the centuries to come" under the certainty of "boundary lists found in Joshua chapters 13 to 19." Israel was then operating a loose social structure of equality and political-economic mobility, in the struggle of every tribe for the control of her territorial possession. ${ }^{\text {xi }}$ Maximization of local tribal lands and their resources was enhanced through network of skills by associated clans till assemblage of clans made a tribe and a confederacy of tribes formed the nation of Israel. National assembly of the tribes was constituted for worship, war/defense and welfare discourses by household heads and clan leaders who brought stewardship contribution of their households, clans and tribes to the senate meeting of the congregation and in the tabernacle (Num. 7:2; 10:4; 11:16\&17; 13:1-3; 17:1-7). Consequently, national revenue for the administration of the confederacy accrued from tithes of proceeds from both private services and household businesses (Lev. 27:30-34; Num. 18:24-32; Deut. $12: 5-14 ; 12: 17 \& 18 ; 14: 22-27)$. Tribal revenue for the running of local towns was gathered from tithes of proceeds from clans and it was expended within individual tribal recognition, not taken to the 
federal capital (Deut. 14:28 \& 29; 26:12-15). The system culminated in "the institution of equality of tribal identity before Yahweh with a sanctuary poll; irrespective of status and gender." As expected, the amalgamation or "the merger of the tribes involved a fusion of several traditions of the cultural and political milieu of the second millennium to have a relative egalitarian system of inter-tribal relations." Yahweh cult became "a paradigm where every tribe was represented by a household leader in providing family identity rite at the shrine of Yahweh." Moreover, "both the poor and the rich were equally required to pay a half shekel" in order "to emphasize a sense of equality of all people regardless of wealth" and as "the standard prize of the Tent of meeting/Tabernacle tax of identification in the presence of God." ${ }^{\text {xvii }}$ This system was in vogue while Israelite settlement existed as a sandwiched confederacy among more military engineered and economically powerful nations of the Ancient Near East. It attracted development to the tribal lands leading to the prosperity of ancient Israel at its settlement before the monarchical age. However, it attracted periodic incursions from the more technologically equipped foreign nations. Israel existed then as a concentration of people in the less populated areas before the development of monarchical structures of city-state. ${ }^{\text {xviii }}$

So, the initial form of socio-economic structures of ancient Israel was the relatively egalitarian system of tribal stewardship that supported its economic buoyancy. This was because; Israelite settlement existed on the basis of concentration of families and tribes within an inter-ethnic community and a territorial unit of extended form of families (that promoted the value of a preservation of equal access to material resources and services of human resources). ${ }^{\text {xix }}$ More so, Israel was a sacred league founded upon: (a) statutes of the covenant with Yahweh, (b) kinship ties through inter-marriage of locally autonomous ethnic-cultural societies, and (c) traditional ideology of social solidarity of rally of tribes that represented the territorial units of every settlement. The league was formed to survive as a self-conscious entity under the most adverse circumstances of Palestine. ${ }^{\mathrm{xx}}$ 
Application of the treaty of amalgamation, stewardship, and continual togetherness that the tribal regions of Israel made among themselves spurred the system of decentralization of control of economic relations for the development of the tribal lands. The treaty of egalitarian stewardship and accountability crafted from Israelite covenant with Yahweh at Sinai was necessary for continual togetherness of the nation because history supplied that the Israelites that settled as an entity at Canaan were a host of mixed multitudes. More so, in the "mixed origin of the Israelites" one discovers that "the patriarchs of Israel migrated around Upper Mesopotamia and Northern Syria, Semitic residents of the Upper Fertile Crescent in Amorite area, and Hurrian settlement in East-Tigris region." They toured "Assyria, Babylonia, Haran and Palestine" in line with "Deut. 26:5-10 that Israelites were initially wandering Arameans/Syrians from Euphrates, beyond the Rivers between Asshur and Ur of Chaldeans (Josh. 24:2-3, 14-15)." The Israelites as "semi-nomads and descendants of Shem, the father of all Eber" were accompanied and covenanted at the Exodus with "some mixed multitude that escaped with them necessitating a national identity conference at Sinai, in the regions of Seir and Midian." Consequently, "there was a treaty of relationship among twelve regions/tribes in a covenant with Yahweh as the Jeshurun King."xxi

The treaty of egalitarian stewardship and accountability was also necessary for continual togetherness of the nation because at the settlement of the Israelites in Palestine, "Israel was crisscrossed with hills that divided many small regions from each other making communication difficult between villages and towns." ${ }^{x i i}$ A decentralized system of government was then put in place "from the beginning of her life in Palestine down to the rise of the monarchy, for a period of some two hundred years." It was a "loosely organized system of (traditionally twelve) tribes.'

A major advantage of the decentralized system was that though, Israel as a "tribal society was patriarchal", social stratification system was foreign to it throughout the Pre- 
Monarchical age. It also maintained social peace by securing "concerted action" through an application of "the sanctions of the covenant." Consequently, "elders of the clans" that formed the nation of Israel were saddled with the adjudication of "dispute in accordance with traditional procedure." In that light, "each tribe was presumably represented by its head" to gather along with other tribal heads at the shrine of Yahweh "located at Shiloh" where the Ark of the Covenant was housed; against "the stratification characteristic of the feudal society of Canaan" that hosted them at the settlement. ${ }^{\text {xxiv }}$

In view of the topography, northern Israel had its "agriculture that depended on rainfall and springs; hence, production was decentralized." In that regard, Israel enjoyed "a tribal tradition of independence from state power" as her villages were "nestled in the hill-country regions." With this tribal self-government, Israel enjoyed an economic and ideological system of plurality for multiplicity during the time of "the isolation and independence of villages."xxv This system provided economic capital and agricultural infrastructure for the rural Israelites. In other words, the provision of rural-based agricultural sector owned by diverse households within a decentralized economic base facilitated the economic buoyancy of the time.

\section{Conclusion}

This paper considered how centralization of economic control in Nigeria caused economic deprivations and poverty among the rural constituent regions. It suggested Israelite egalitarian system of stewardship and accountability for a decentralization of economic control towards improvement of the rural constituent regions. This paper also recognized that good governance to every average Nigerian should include (a) amelioration of economic deprivation that caused entrepreneurial poverty and (b) reduction of rate of crime in the process of wealth-creation that concentrated on the cities. Hence, it assumed that national development should encourage the ideals of good governance that promote: (i) establishment of manufacturing industries that ensure employment of labour to render 
sustainable services, (ii) stewardship and accountability of the rural constituent regions, (iii) clarity of needs and goals by creation of expertise through professional training systems of skilled labour reproduction at the rural base, (iv) precise job description and hours of stewardship, (v) transparent delegation of authority, (vi) submission and obedience of the subsets to the Federal Government, (vii) sportsmanship spirit among the subsets, (viii) extra cooperative effort of solidarity for interdependence and unity among the subsets, and (ix) an evaluative method that rewards loyalty to laid-down rules and due process or approved pattern of relationship, among others. These ideals assist in awakening the required sense of equality and egalitarian system of: extracting, producing, distributing and supplying or contributing the natural, material, social and human resources from the individual subsets of the sum total. They provide as well a platform for wealth-creation or prosperity and for building trust among different ethnic, cultural and multi religious identities that make-up an indistinguishable political and economic unit called a nation in her transition from rural to urban life.

In view of the foregoing, this study also advocates a decentralization of control of economic relations from the Federal and State Governments to the Local Governments. It suggests that industries as factories of employment should be located and localized in the rural areas where both human resources and raw materials are readily available. It assumes that a decentralized control of economic relations will assist in developing the rural life and attract the presence of Federal, State and Local Governments in building the rural setting with hospitals, schools and good road channelization. These provisions will in turn reduce mass migration of human resources from the rural areas to the urban areas and reduce crime rate in the cities.

Moreover, decentralization of economic control is recommended because city life is known with mass settlement of people in highly populated locations or existence of unidentifiable number and categorization of city inhabitants. Due to high 
concentration of people in the urban areas, cost of living increases amidst the obvious recognition of more prospective employees and job-seekers than the number and capacity of firms, factories and industries available to offer employment that provides occupational mobility and easier change of status. Socio-economic deprivation as a form of poverty attends the concentration of more job-seekers above the employment opportunities in the urban centres. Job security and assurance of provisions for a change of status within occupational mobility become privileges for employees as employers have more prospective employees at their disposal to replace every dispensable employee. So, urbanization foments the challenges of creation of industrial estates and residential quarters for the mass movement of the labour force, employees, job-seekers and menial-hard workers migrating from the rural to develop the urban.

Similarly, rate of crime is known to increase with growth in number of people populating a locality at a given time. Economic and social misdemeanors are also found multiplying as the identity of daily means of earning a living or wage earning jobs of every resident becomes indefinite, immeasurable and beyond estimate. Current ethnic-militia unrest, political kidnapping and religiopolitical rebellion against Adamawa, Yobe and Borno States in Nigeria called Boko-Haram will drastically reduce if not wiped out as the over-population factor in the cities constituting these states disperses.

Consequently, Federal and State Governments should withdraw from encroaching into private entrepreneurial ingenuity of every region and economic legerdemain of local towns' trade unions. State controlled corporations that make stifling economic policies with task forces to check entrepreneurial creativity of private businesses in every region should be scrapped. Financial assistance from the FGN/SGs should be given to thriving unions of private firms, local farmers and manufacturers of primary products at LGs; to improve their productions and in turn their contributions that will accrue as stewardship and accountability for the 
Ogirisi: a new Journal of African Studies vol 102013

development of the nation. Every attempt should be made to promote establishment of local factories and manufacture of food, cash and primary products, in order to reduce and wipe out exploitation of agricultural food and cash crops, mineral resources and primary products from Nigeria by foreign lands and impostors. Promotion of entrepreneurial creativity in the local towns of every region will retain man power in the local towns and relocate the initial migration of human resources (from small towns to urban centres) back to the local towns where industries are sited. Plantations of food and cash crops will reemerge as employment avenues for Nigerian masses and youths in the rural areas.

On appropriation of the egalitarian system of stewardship of every region constituting Nigeria, this study proposes that $20 \%$ of Gross Rural Profits (GRPs) from every region of Nigeria should be sent periodically to the Federal Government as local contribution towards federal/national treasury. Another 20\% of GRPs from every region of Nigeria should be sent periodically to the State Government that the regions belong to as their local contribution towards the treasury of their State Governments. The rest $60 \%$ of GRPs from every region should be retained at the local/rural factories of productions, employment of labour, and generation of primary products to address their challenges and secure healthy economic base.

In addition, the value of meeting the needs of people as a springboard of being decorated with local village/communal title and award will return to the regions constituting Nigeria when there is decentralization of economic control at the Federal and State levels. This is because; village life includes settlement of inhabitants at less populated locations within the recognition of individual household, family-compound or territorial unit. This rural setting will enable easier, simple and direct recognition of every resident of a locality and his/her occupation. More so, villages or local settlements have among their characteristics the intense monopoly of occupational or vocational identity, location of clan or household farm-land in a 
neighbouring forest and agrarian farm land, remuneration of services by reciprocal exchange of services from age-group caucuses, acknowledgment and respect of community development by social solidarity, preference for a less mobile change of status and a simple relatively egalitarian distribution of occupation and traditional titleholding. There will also be an easier identification of the citizenry of the community and the availability of reciprocal exchange of services rendered on the basis of social solidarity. These among other advantages of locating factories as industries of employment in proximity of raw materials resident in the rural areas will reduce the current rate of crime in Nigeria.

*Abiola A. Olaniyi is a lecturer in the Department of Religious Studies, Obafemi Awolowo University, Ile-Ife, Nigeria. aaolaniyi@gmail.com 


\section{References}

J. Ekejiuba 2000. "The Masses and Elusive Democratic Gains." The Punch, $19^{\text {th }}$ September, p. 33.

ii G. Arnold, 2005. "Industrialization and Development" in Kevin Shillington (ed.). Encyclopedia of African History Volume 1 A-G. New York: Taylor and Francis Group, pp. 677-678.

iii L. Mathe-Shires, 2005. "Nigeria: British Colonization to 1914" in Kevin Shillington (ed.). Encyclopedia of African History Volume 1 A-G. New York: Taylor and Francis Group, pp. 1095-1098.

iv F. Afolayan, 2005. "Yoruba States: Trade and Conflict, Nineteenth Century" in Kevin Shillington (ed.). Encyclopedia of African History Volume 1 A-G. New York: Taylor and Francis Group, pp. 1685-1686.

v L. Mathe-Shires, 2005. "Nigeria: British Colonization to 1914" in Kevin Shillington (ed.). Encyclopedia of African History Volume 1 A-G. New York: Taylor and Francis Group, pp. 1095-1098.

vi R.A. Goodridge, 2005. "Labour: Decline in Traditional Forms of Exploitation" in Kevin Shillington (ed.). Encyclopedia of African History Volume 1 A-G. New York: Taylor and Francis Group, pp. 784-786.

${ }^{\text {vii }}$ L. Mathe-Shires, 2005. "Nigeria: British Colonization to 1914" in Kevin Shillington (ed.). Encyclopedia of African History Volume 1 A-G. New York: Taylor and Francis Group, p. 1095.

viii P.J. Schraeder, 2004. African Politics and Society: A Mosaic in Transformation. Wadsworth: Cengage Learning, pp. 210-214.

${ }^{\text {ix }}$ S.M. Nwaomah, 2006. "Human Trafficking As De-Imaging Humanity in Nigeria: A Contextual Study of Genesis 1:26-27." in Religion, Governance and Development in the 21st Century. Ilorin: National Association for the Study of Religions (NASR), p. 315.

${ }^{x}$ M. Micheal and I. Robertson, 1975. Social Problems. New York: Random House, p. 255.

xi O. Awowede, 2000. "Poverty in the Midst of Plenty," The Tell, 9th October, p. 26.

xii S.O. Abogunrin, 1986. "The Community of Goods in Early Church and the Distribution of National Wealth" in African Journal of Biblical Studies Vol. 4, No. 2, p. 84.

xiii G.A. Ositelu, 2001. "Religion and Poverty Alleviation in Nigeria" in Orita Ibadan Journal of Religious Studies Vol. XXX III, No 1 \& 2, p. 80. 
xiv G.A. Ositelu, 2001. "Religion and Poverty Alleviation in Nigeria" in Orita Ibadan Journal of Religious Studies Vol. XXX III, No 1 \& 2, p. 77.

${ }^{x v}$ M. Chaney, 1983. "Ancient Palestinian Peasant Movements and the Formation of Pre-monarchic Israel" in D. N. Freedman and D. F. Graf (eds). Palestine in Transition: The Emergence of Ancient Israel. Sheffields Almond: Social World of Biblical Antiquity Series, p. 50.

${ }^{\mathrm{xvi}}$ J. Bright, 1984. A History of Israel. Third Edition. London: SCM Press Ltd, p. 165.

xvii A.A. Olaniyi, 2012. "The Gebira Role in the Ancient Israelite Royal Cult and Women Leadership in Ile-Ife Zone of Cherubim And Seraphim Churches" in AFRICANA Vol. 6, No. 1, pp. 270-271.

${ }^{x v i i i}$ M. Chaney, 1983. "Ancient Palestinian Peasant Movements and the Formation of Pre-monarchic Israel" in D. N. Freedman and D. F. Graf (eds). Palestine in Transition: The Emergence of Ancient Israel. Sheffields Almond: Social World of Biblical Antiquity Series, p. 49.

${ }^{x i x}$ N. Gottwald, 1979. The Tribes of Yahweh: A Sociology of the Religion of Liberated Israel. 1250 - 1050 B.C.E.. Maryknoll: Orbis Books, p. 465.

${ }^{\mathrm{xx}} \mathrm{J}$. Bright, 1984. A History of Israel. Third Edition. London: SCM Press Ltd, pp. $162-163$.

${ }^{x x i}$ A.A. Olaniyi, 2012. "The Gebira Role in the Ancient Israelite Royal Cult and Women Leadership in Ile-Ife Zone of Cherubim And Seraphim Churches" in AFRICANA Vol. 6, No. 1, pp. 269-270.

xxii T.H. Renteria, 1992. "The Elijah/Elisha Stories: A Socio-cultural Analysis of Prophets and People in Ninth-Century B.C.E. Israel" in Robert B. Coote (ed.) Elijah and Elisha in Socio-literary Perspective. Atlanta, Georgia: Scholars Press, pp. 87-88.

xxiii J. Bright, 1984. A History of Israel. Third Edition. London: SCM Press Ltd, p. 162.

${ }^{\text {xxiv }}$ J. Bright, 1984. A History of Israel. Third Edition. London: SCM Press Ltd, p. 166.

xxv T.H. Renteria, 1992. "The Elijah/Elisha Stories: A Socio-cultural Analysis of Prophets and People in Ninth-Century B.C.E. Israel" in Robert B. Coote (ed.) Elijah and Elisha in Socio-literary Perspective. Atlanta, Georgia: Scholars Press, p. 85. 